\title{
CARCINOMA UPPER LIP, TREATED BY WIDE EXCISION AND RECONSTRUCTION USING BILATERAL NASOLABIAL FLAPS CLOSED BY ' Z' PLASTY TECHNIQUE: A SURGICAL CASE REPORT
}

\author{
A. Veerasigamani ${ }^{1}$, R. Kannan ${ }^{2}$, Reena Rachel John ${ }^{3}$,Karthik Kumaran ${ }^{4}$,V. Narendra Kumar ${ }^{5}$
}

\section{HOW TO CITE THIS ARTICLE:}

A. Veerasigamani, R. Kannan, Reena Rachel John, Karthik Kumaran, V. Narendra Kumar."Carcinoma Upper Lip, Treated by Wide Excision and Reconstruction using Bilateral Nasolabial Flaps Closed by 'Z' Plasty Technique: A Surgical Case Report". Journal of Evolution of Medical and Dental Sciences 2014; Vol. 3, Issue 32, August 04; Page: 8839-8845, DOI: 10.14260/jemds/2014/3132

ABSTRACT: Lip cancer is the most frequent malignant neoplasm of the oral cavity. Lower lip is the most common site. Defects larger than one-fourth of total upper lip length require reconstruction by established techniques or multiple procedures. Nasolabial rotation flaps based on the upper lateral lip subunit for superficial and large defects of the upper lateral lip are proposed. We report a case of 60 year old female who presented to us with ulceroproliferative growth over the upper lip for 6 months. Edge biopsy proved it as squamous cell carcinoma. We surgically treated this patient with wide excision of the primary lesion and selective neck dissection followed by reconstruction using bilateral nasolabial flaps closed by Z plasty technique.

KEYWORDS: Nasolabial flap, Selective neck dissection, Supraomohyoid neck dissection, Squamous cell carcinoma, Upper lip, Vermillion border.

INTRODUCTION: The incidence of lip cancer is high in males (95\%) when compared to females (5\%). The majority of neoplastic lesions that affect lips are present on the lower (88\% to 95\%) as opposed to the upper lip (2\% to $7 \%$ ) or the commissure $(1 \%)$. For the lower lip, squamous cell carcinoma predominates, whereas basal cell carcinoma is common on the upper lip. ${ }^{1}$ The diagnosis of squamous cell carcinoma can be clinically suggestive, but it is essential for squamous cell carcinoma to be histologically confirmed.2

In advanced stages of squamous cell carcinoma, microsurgery is usually recommended. There is no 'gold standard' criteria for large reconstruction of both upper and lower lips; especially in squamous cell carcinoma. ${ }^{3}$ Nasolabial rotation flaps based on the upper lateral lip subunit for superficial and large defects of the upper lateral lip are proposed ${ }^{4}$ We report a case of 60 year old female who presented to us with ulceroproliferative growth over the upper lip.

Edge biopsy proved it as squamous cell carcinoma. We surgically treated this patient with wide excision of the primary lesion and selective neck dissection followed by reconstruction using bilateral nasolabial flaps closed by Z plasty technique.

\section{MATERIALS AND METHODS:}

CASE REPORT: A 60 year old female came to our hospital with the complaints of ulcer over the upper lip for 6 months, which was gradual in onset and progressive in nature. Patient is a farmer by occupation with history of excessive sun exposure. She is not a smoker or betel nut chewer.

On examination, $4 * 3 \mathrm{~cm}$ size ulceroproliferative growth involving two thirds of the upper lip (middle portion) was present. Edges were everted with indurated base. Floor was covered with necrotic material (Figure 1-4). 
There is no evidence of underlying muscle or periosteal involvement. Submandibular lymph node on the right side was enlarged. Edge biopsy of the lesion was done, which proved to be a squamous cell carcinoma.

We started with supraomohyoid selective neck dissection and removed submandibular neck nodes (Figure 5). The marking for the incision to remove primary lesion was made (Figure 6). Then we did a wide excision of the primary lesion with $1 \mathrm{~cm}$ margin. The marking for the Nasolabial flap was made (Figure 7) and bilateral Nasolabial flaps were raised (Figure 8). First vermillion border was approximated (Figure 9,10). The nasolabial flap on the right side is mobilized to cover the defect and Nasolabial flap on the left side was advanced downwards to prevent tension and microstomia and sutured with the contralateral flap in a Z plasty technique (Figure 11).

RESULTS: On follow up of the patient after 6 months, the lesion completely cleared with no reconstruction defects (Figure 12-15) and there were no enlarged neck nodes clinically.

DISCUSSION: Oral cavity cancer is the sixth leading cause of cancer worldwide ${ }^{5}$. Carcinoma of the lip occurs most frequently in older white men, with the average age at onset being the sixth decade of life, its incidence being 1-2\%. It appears that the major risk factors for the development of lip cancer are male gender, a fair ruddy complexion, and an outdoor occupation. The other factors include poor dental hygiene, syphilis, chronic alcoholism, and pipe smoking.

The lip, especially the lower lip is the most common site of origin for squamous cell carcinoma of the oral cavity. The clinical behavior of carcinoma of the lip, more closely resembles that of squamous cell carcinoma of the skin. Squamous cell carcinoma typically presents as an obvious, exophytic, ulcerated lesion with a greyish necrotic base and an associated margin of induration. Histologically, the tumor consists of irregular nests, columns, or strands of malignant epithelial cells infiltrating subepithelially. ${ }^{6}$

Neck metastasis is the most important prognostic factor in head and neck squamous cell carcinomas $^{7}$. The incidence of regional nodal metastasis has been found to be $5 \%$ for T1 lesions, $50 \%$ for T2 lesions, and 70\% for T3 lesions. Supraomohyoid neck dissection (SOHND) is generally considered an adequate staging procedure in selected patients with squamous cell carcinoma (SCC) of the lip and oral cavity8.Numerous techniques have been developed for lip reconstruction; the choice depending on the position of the lesion, its extension and the presence of any metastases to lymph nodes. ${ }^{9}$

In the upper lip, defects can be divided into less than one-third, one-third to two-thirds and greater than two-thirds to complete defects. Defects of less than one-third in the midline can be closed primarily. Defects between one-third and two-thirds can be reconstructed with cross lip flaps from the lower lip. They are Perialar crescentric, Reverse Karapandzic free flap, Abbe Estlander flap. For the defects greater than two-thirds of the upper lip, Burrow-Diffenbach reconstruction can be performed. ${ }^{10}$

Nasolabial flap is a very useful and simple alternative to other pedicled flaps and free flaps for reconstruction of smaller defects of the oral mucosa in different anatomic locations of the oral cavity. More frequently bilateral random NLFs are required depending on the site and size of defects. ${ }^{11}$ The nasolabial flap can also be used as an interpolation flap in either a single or a staged technique. ${ }^{12}$ 
Accurate approximation of the vermilion border of the flap with that of the defect will ensure a good cosmetic result. The surgeon should recall that the vermilion border is an important guide, because the labial artery runs just deep to the muscle at the level of the vermilion border. ${ }^{13}$ Any reconstruction of the lip should respect the principle that the tension for closure of the primary and/or secondary defect should be parallel to the axis of the lip and the incision lines should as far as possible be perpendicular to the axis of the lip. ${ }^{14}$

The prognosis of a 5-year survival is worse for tumors of the upper lip and commissure than for those of the lower lip. The probability of survival up to 5 years is lower in cases with involvement of the lymph nodes; the rate is $50 \%$ if nodes are involved and $25 \%$ in the presence of capsular breakage or bone infiltration.

CONCLUSION: The choice of surgical approach for lip cancers is very important, as it decides the better aesthetic, functional and prognostic outcome in future. The aim of the surgery should be preservation of lip function (speech, chewing, oral competence, and retention of saliva) and satisfactory cosmetic appearance.

Reconstruction using Nasolabial flaps is versatile by preserving the normal facial appearance with minimal donor site morbidity. Excellent aesthetic reconstructive results are easily achieved by appropriate patient selection and preoperative planning. As in our case, closure of bilateral Nasolabial flaps by Z plasty technique will prevent microstomia and tension of flaps which provide a good cosmetic result.

\section{REFERENCES:}

1. Paul W Flintet al. Cummings Otolaryngology-Head and Neck Surgery. 5th ed. Philadelphia: Mosby Elsevier Publishing; 2010.

2. Dong Yeon Kim et al.Squamous Cell Carcinoma on the Upper Lip of a Patient with Discoid Lupus Erythematosus.Arch PlastSurg, Mar 2013; 40(2):155-157.

3. ChairatBurusapat,AnontPitiseree.Advanced squamous cell carcinoma involving both upper and lower lips and oral commissure with simultaneous reconstruction by local flap: a case report.Journal of Medical Case Reports, 2012, 6:23 doi:10.1186/1752-1947-6-23.

4. Burget GC, Hsiao YC.Nasolabial rotation flaps based on the upper lateral lip subunit for superficial and large defects of the upper lateral lip. PlastReconstrSurg, 2012, Sep;130(3):55660.

5. Jatin P Shah. Cancer of the Head and Neck. 4thed, New york: BC Decker Inc Publishing; 2001.

6. Paul Q. Montgomery et al.Head and NeckSurgery and Oncology, 2nd ed, London: Informa UK Ltd publishing; 2009.

7. LP Kowalski, ASanabria.Elective neck dissection in oral cavity: a critical review of the evidence.ActaOtorhinolaryngolItal, Jun 2007; 27(3): 113-117.

8. Gooris PJ et al.Supraomyohyoid neck dissection in the management of cervical lymph node metastases of squamous cell carcinoma of the lower lip.Head Neck.2002, Jul;24(7):678-83.

9. Moretti et al. Surgical management of lip cancer.ActaOtorhinolaryngolItal, Feb 2011; 31(1): 510.

10. Michael Gleeson et al. Scott-Brawn's Otorhinolaryngology, Head and Neck Surgery, 7thed, Great Britain: Hodder Arnold Publishing; 2008. 
11. Sailesh Kumar Mukul et al.Inferiorly Based Nasolabial Flap As A Backup Flap -A Surgical Case Report, Int. Journal of Clinical Dental Science, September, 2012, 3(2).

12. Seema Singh et al.Nasolabial flap reconstruction in oral cancer.World Journal of Surgical Oncology, 2012, 10:227.

13. Eugene N Myers et al.Operative Otolaryngology Head and Neck Surgery, 2nd ed, Philadelphia: Saunders Elsevier publishing; 2008.

14. A.M. SKaria.The Transposition Advancement Flap for Repair of Postsurgical Defects on the Upper Lip.Dermatology, 2011;223:203-206.

Figure 1-4: Ulceroproliferative growth involving two thirds of the upper lip.

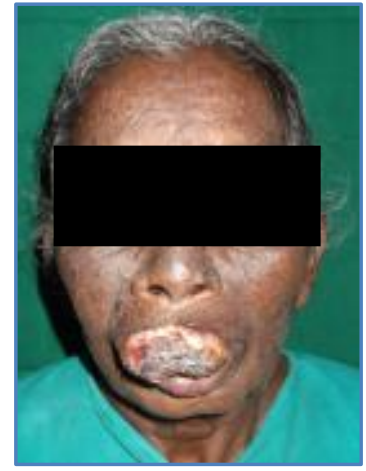

Fig. 1

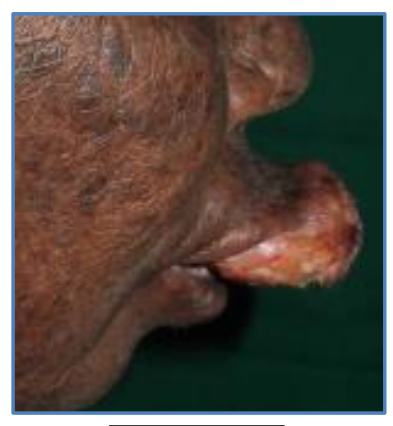

Fig. 3

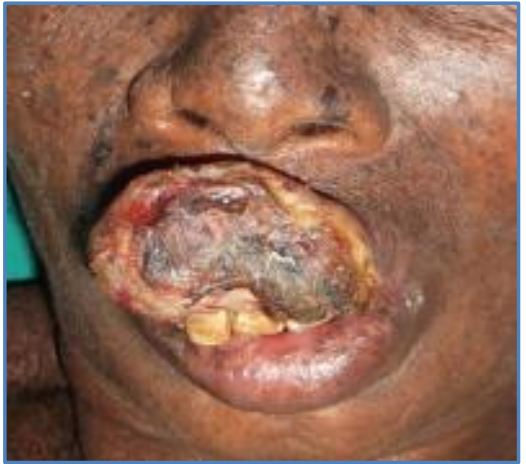

Fig. 2

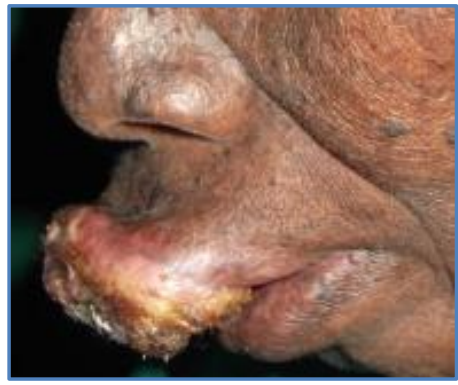

Fig. 4

Figure 5: Supraomohyoid selective neck dissection.

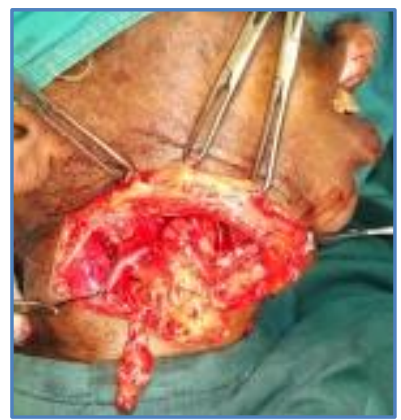

Fig. 5 


\section{CASE REPORT}

Figure 6: The marking for the incision to remove primary lesion.

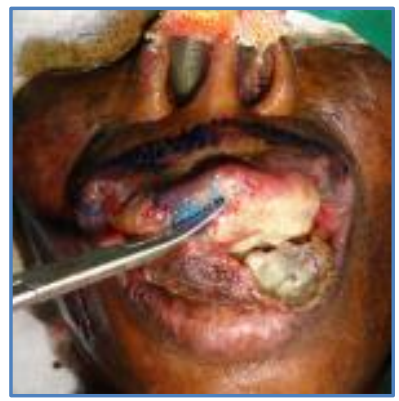

Fig. 6

Figure 7: Primary defect is removed and the marking for the Nasolabial flap was made.

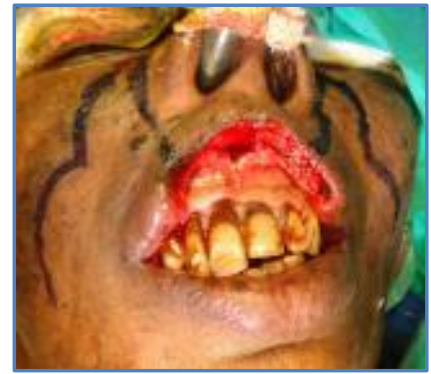

Fig. 7

Figure 8: Bilateral Nasolabial flaps were raised.

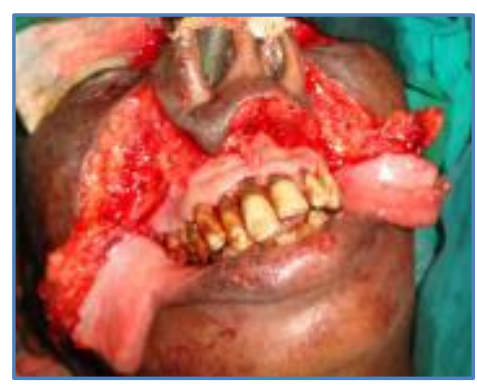

Fig. 8

Figure 9, 10: Vermillion border was approximated.

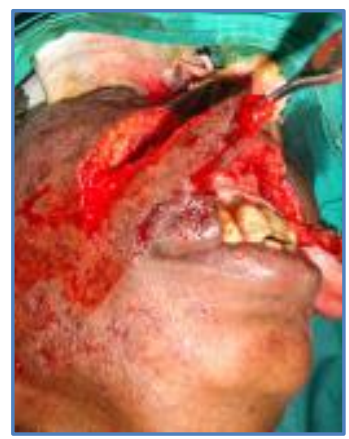

Fig. 9

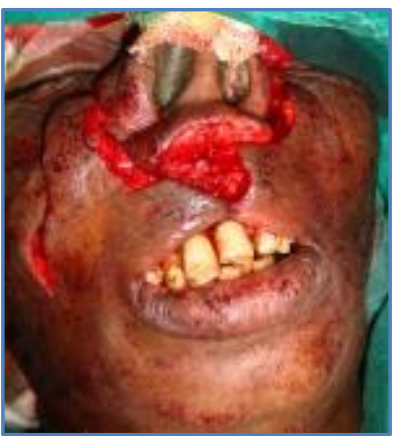

Fig. 10 


\section{CASE REPORT}

Figure 11:Nasolabial flap sutured in a $\mathrm{Z}$ plasty technique.

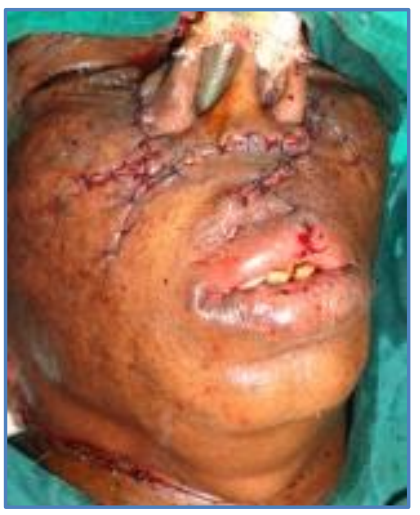

Fig. 11

Figure 12-14: Post op view after 6 months. Showing the clearance of the disease without any reconstruction defects .
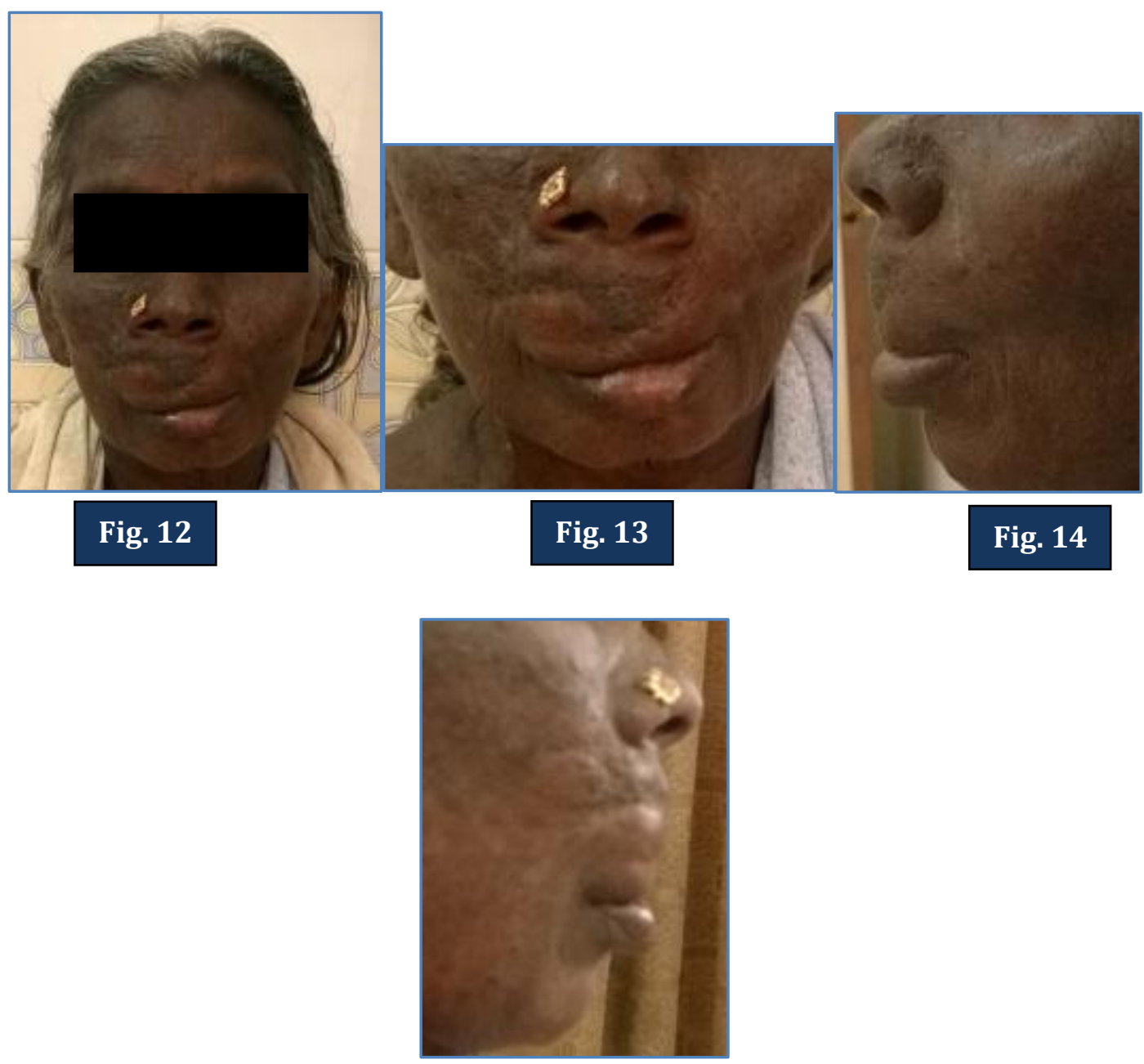

Fig. 15 


\section{CASE REPORT}

\section{AUTHORS:}

1. A. Veerasigamani

2. R. Kannan

3. Reena Rachel John

4. Karthik Kumaran

5. V. Narendra Kumar

\section{PARTICULARS OF CONTRIBUTORS:}

1. Assistant Professor, Department of Plastic Surgery, Vinayaka Mission's Kirupananda Variyar Medical College \& Hospitals, Salem.

2. Professor, Department of Oral \& Maxillofacial Surgery, Vinayaka Mission's Kirupananda Variyar Medical College \& Hospitals, Salem.

3. Professor, Department of Oral \& Maxillofacial Surgery, Vinayaka Mission's Kirupananda Variyar Medical College \& Hospitals, Salem.

4. Junior Resident, Department of General Surgery, Vinayaka Mission's Kirupananda Variyar Medical College \& Hospitals, Salem.
5. Junior Resident, Department of ENT, Aarupadai Veedu Medical College and Hospital, Puducherry.

\section{NAME ADDRESS EMAIL ID OF THE CORRESPONDING AUTHOR:}

Dr. A. Veerasigamani,

No. 88, 89,

S. K. City,

Dasanaikenpatty,

Salem- 636201.

Email: drnarenkapv@yahoo.com

Date of Submission: 17/07/2014.

Date of Peer Review: 18/07/2014.

Date of Acceptance: 28/07/2014.

Date of Publishing: 04/08/2014. 